\title{
Content and Correlational Analysis of a Corpus of MTV-Promoted Music Videos Aired Between 1990 and 1999
}

Music \& Science Volume 3: I-14

(C) The Author(s) 2020 Article reuse guidelines: sagepub.com/journals-permissions DOI: I0.I I77/2059204320902369 journals.sagepub.com/home/mns

(\$)SAGE

\author{
Brad Osborn $₫$, Emily Rossin and Kevin Weingarten $₫$
}

\begin{abstract}
From 1990 to 1999 MTV promoted a series of 288 music videos called "Buzz Clips", designed to highlight emerging artists and genres. Such promotion had a measurable impact on an artists' earnings and record sales. To date, the kinds of musical and visual practices MTV promoted have not been quantitatively analyzed. Just what made some videos Buzzworthy, and others not? We applied two phases of content analysis to this corpus to determine the most common sonic and visual signifiers in Buzz Clips, then processed the results of that content analysis using polychoric correlations. Our findings show high degrees of shared variance between certain pairs of musical and visual elements observed in the sample music videos. We interpret a number of these relationships in terms of their relevance to a performer's perceived ethnicity and gender, showing how certain audiovisual features regularly accompany white men (e.g., electric guitar) while others regularly accompany women and performers of color (e.g. drum machines).
\end{abstract}

\section{Keywords}

Buzz Clips, content analysis, correlational analysis, MTV, music video

Submission date: 18 April 2019; Acceptance date: 7 January 2020

\section{Introduction}

Recent research in music videos has applied a number of distinct approaches from different academic disciplines, especially popular music, ${ }^{1}$ film and media studies (Caston, 2017; Korsgaard, 2013; Vernallis, 2013), gender and sexuality (Benson-Alcott, 2013), and critical race theory (Balaji, 2010; Reid-Brinkley, 2008). Several authors have attempted to combine approaches derived from each of these fields into an interdisciplinary study (Lafrance \& Burns, 2017). The current study aims to augment this significant body of research by detailing a decade of musical and visual elements observable in a set of music videos and applying correlational analysis to draw conclusions about relationships between those variables.

Our corpus for this study is a series of 288 music videos MTV promoted in the 1990s as "Buzzworthy," from the "Buzz Bin," or simply as "Buzz Clips."2 Such videos were instantly recognizable as such, bearing an iconic "BUZZ BIN" logo alongside the video's ID tags. Additionally, Billboard's Video Monitor publication indicated which videos were being promoted as Buzz Clips with an asterisk. MTV itself recorded the complete list of such videos on a nowdefunct website. ${ }^{3}$ Table 1 shows the metadata for all videos analyzed in our corpus, including artist, video title, month of premiere, and peak position on the Billboard Hot 100 chart (if applicable).

A number of hypotheses might be made about why these particular 288 videos were deemed "Buzzworthy." There is, of course, a commercial incentive. According to Entertainment Weekly (1995), by 1994, an artist's Buzz Clip was $\sim 75 \%$ likely to earn its corresponding album gold or platinum sales. In addition, the "payola" schemes between the network and record companies have been well documented (Banks, 1997). Andy Schuon, then Executive Vice President at MTV, once said "The Buzz Bin is our way of saying

University of Kansas, Lawrence, KS, USA

Corresponding author:

Brad Osborn, University of Kansas, I I 29 Oregon St, Lawrence, KS 66044, USA.

Email: bradosborn@ku.edu 
Table I. Metadata for all videos analyzed in the corpus.

\begin{tabular}{|c|c|c|c|}
\hline Artist & Video & Premiere Date & Billboard Hot 100 Peak Position \\
\hline The La's & There She Goes & $1 / 89$ & 49 \\
\hline The KLF & 3 am Eternal & $5 / 89$ & 5 \\
\hline Smithereens, The & A Girl Like You & $10 / 89$ & 38 \\
\hline Jesus Mary Chain, The & Head On & $10 / 89$ & - \\
\hline Depeche Mode & Personal Jesus & $11 / 89$ & 28 \\
\hline Psychedelic Furs & House & $12 / 89$ & - \\
\hline Kate Bush & Love and Anger & $12 / 89$ & - \\
\hline Sinead O'Connor & Nothing Compares $2 \mathrm{U}$ & $1 / 90$ & I \\
\hline Peter Murphy & Cuts You Up & $1 / 90$ & 55 \\
\hline Blue Nile, The & The Downtown Lights & $1 / 90$ & - \\
\hline Jesus Jones & Real, Real, Real & $3 / 90$ & 4 \\
\hline Depeche Mode & Enjoy the Silence & $3 / 90$ & 8 \\
\hline Cure, The & Pictures of You & $3 / 90$ & 71 \\
\hline House of Love & I Don't Know Why I Love You & $3 / 90$ & - \\
\hline Mission U.K., The & Deliverance & $3 / 90$ & - \\
\hline Church, The & Metropolis & $3 / 90$ & - \\
\hline NIN & Head Like a Hole & $3 / 90$ & - \\
\hline Lightning Seeds, The & Pure & $4 / 90$ & 31 \\
\hline Happy Mondays & Step On & $4 / 90$ & 57 \\
\hline The Sundays & Here's Where the Story Ends & $4 / 90$ & - \\
\hline Midnight Oil & Forgotten Years & $5 / 90$ & - \\
\hline D.N.A. ft. Suzanne Vega & Tom's Diner & $6 / 90$ & 5 \\
\hline Gene Loves Jezebel & Jealous & $6 / 90$ & 12 \\
\hline Concrete Blonde & Joey & $6 / 90$ & 19 \\
\hline Charlatans U.K. & The Only One I Know & $6 / 90$ & - \\
\hline Adrian Belew & Pretty Pink Rose & $7 / 90$ & 1 \\
\hline Soup Dragons & I'm Free & $7 / 90$ & 79 \\
\hline Sonic Youth & Kool Thing & $7 / 90$ & - \\
\hline Aztec Camera & The Crying Scene & $7 / 90$ & - \\
\hline Midnight Oil & King of the Mountain & $8 / 90$ & - \\
\hline World Party & Way Down Now & $8 / 90$ & - \\
\hline Jesus Jones & Right Here, Right Now & $9 / 90$ & 2 \\
\hline Urban Dance Squad & Deeper Shade of Soul & $9 / 90$ & 21 \\
\hline The Farm & Groovy Train & $9 / 90$ & 41 \\
\hline Cure, The & Never Enough & $9 / 90$ & 72 \\
\hline Replacements, The & Merry Go Round & $9 / 90$ & - \\
\hline Jane's Addiction & Stop! & $9 / 90$ & - \\
\hline Enigma & Sad(e?)ness, Part I & $10 / 90$ & 5 \\
\hline Iggy Pop & Candy & $10 / 90$ & 28 \\
\hline Cure, The & Close to $\mathrm{Me}$ & $10 / 90$ & 97 \\
\hline Neneh Cherry & I've Got You Under My Skin & $10 / 90$ & - \\
\hline EMF & Unbelievable & $11 / 90$ & I \\
\hline U2 & Night and Day & $11 / 90$ & - \\
\hline Jane's Addiction & Been Caught Stealing & $11 / 90$ & - \\
\hline King's $X$ & It's Love & $11 / 90$ & - \\
\hline Seal & Crazy & $12 / 90$ & 7 \\
\hline Jellyfish & That is Why & $1 / 91$ & - \\
\hline Alice in Chains & Man in the Box & $|/ 9|$ & - \\
\hline Bingo Boys & How to Dance & $2 / 91$ & 25 \\
\hline Monie Love & It's a Shame & $2 / 91$ & 26 \\
\hline Living Colour & Love Rears its Ugly Head & $2 / 91$ & - \\
\hline Simple Minds & See the Lights & $3 / 91$ & 40 \\
\hline Lenny Kravitz & Always on the Run & $3 / 91$ & - \\
\hline Rembrants, The & That's Just the Way & $4 / 91$ & 14 \\
\hline Jellyfish & Baby's Coming Back & $4 / 91$ & 62 \\
\hline Definition of Sound & Now is Tomorrow & $4 / 91$ & - \\
\hline The Divinals & I Touch Myself & $5 / 91$ & 4 \\
\hline
\end{tabular}


Table I. (continued)

\begin{tabular}{|c|c|c|c|}
\hline Artist & Video & Premiere Date & Billboard Hot 100 Peak Position \\
\hline Crystal Waters & Gypsy Woman & $5 / 91$ & 8 \\
\hline La Tour & People are Still Having Sex & $5 / 91$ & 35 \\
\hline Siouxsie/Banshees & Kiss Them for Me & $5 / 91$ & 91 \\
\hline Elvis Costello & The Other Side of Summer & $5 / 91$ & - \\
\hline 3rd Bass & Pop Goes the Weasel & $6 / 91$ & 29 \\
\hline Drivin' N Cryin' & Build a Fire & $6 / 91$ & - \\
\hline Daddy Freddy & Daddy Freddy's in Town & $6 / 91$ & - \\
\hline Thunder & Dirty Love & $7 / 91$ & 55 \\
\hline White Trash & Apple Pie & $7 / 91$ & - \\
\hline Toni Childs & I've Got to Go Now & $7 / 91$ & - \\
\hline PM Dawn & Set Adrift on Memory Bliss & $8 / 91$ & I \\
\hline EMF & Lies & $8 / 91$ & 18 \\
\hline Ned's Atomic Dustbin & Grey Cell Green & $8 / 91$ & - \\
\hline Julian Lennon & Saltwater & $8 / 91$ & - \\
\hline Nirvana & Smells Like Teen Spirit & $9 / 91$ & 6 \\
\hline RHCP & Give it Away & $9 / 91$ & 73 \\
\hline Pearl Jam & Alive & $9 / 91$ & - \\
\hline PM Dawn & Paper Doll & $10 / 91$ & 28 \\
\hline Big Audio Dynamite II & Rush & $10 / 91$ & - \\
\hline Seal & Killer & ||$/ 9 \mid$ & 100 \\
\hline Teenage Fanclub & The Concept & $|1 / 9|$ & - \\
\hline Soundgarden & Outshined & $12 / 9 \mid$ & - \\
\hline Shakespears [sic] Sister & Stay & $1 / 92$ & 4 \\
\hline Live & Operation Spirit & $1 / 92$ & - \\
\hline Matthew Sweet & Girlfriend & $1 / 92$ & - \\
\hline Sugarcubes & Hit & $1 / 92$ & - \\
\hline RHCP & Under the Bridge & $2 / 92$ & 2 \\
\hline Primal Scream & Movin' on Up & $2 / 92$ & - \\
\hline Live & Pain Lies on the Riverside & $2 / 92$ & - \\
\hline Social Distortion & Bad Luck & $3 / 92$ & - \\
\hline Cracker & Teen Angst & $3 / 92$ & - \\
\hline Soundgarden & Rusty Cage & $3 / 92$ & - \\
\hline Beastie Boys & Pass the Mic & $3 / 92$ & - \\
\hline Soup Dragons & Divine Thing & $4 / 92$ & 35 \\
\hline Pearl Jam & Even Flow & $4 / 92$ & - \\
\hline King's $X$ & Black Flag & $4 / 92$ & - \\
\hline Arrested Development & Tennessee & $5 / 92$ & 6 \\
\hline Beastie Boys & So Whatcha Want? & $5 / 92$ & 93 \\
\hline Midnight Oil & Sometimes (Live) & $5 / 92$ & - \\
\hline XTC & Ballad of Peter Pumpkinhead & $5 / 92$ & - \\
\hline Utah Saints & Something Good & $6 / 92$ & 98 \\
\hline Faith No More & Midlife Crisis & $6 / 92$ & - \\
\hline Alice in Chains & Would? & $6 / 92$ & - \\
\hline Sonic Youth & $100 \%$ & $7 / 92$ & - \\
\hline Helmet & Unsung & $8 / 92$ & - \\
\hline Morrissey & Tomorrow & $8 / 92$ & - \\
\hline Stereo MCs & Connected & $9 / 92$ & 20 \\
\hline Blind Melon & No Rain & $9 / 92$ & 20 \\
\hline Gin Blossoms & Hey Jealousy & $9 / 92$ & 25 \\
\hline Tasmin Archer & Sleeping Satellite & $9 / 92$ & 32 \\
\hline Alice in Chains & Them Bones & $9 / 92$ & - \\
\hline Faith No More & A Small Victory & $9 / 92$ & - \\
\hline 10,000 Maniacs & These are the Days & $10 / 92$ & 66 \\
\hline Temple of the Dog & Hunger Strike & $10 / 92$ & - \\
\hline Soul Asylum & Somebody to Shove & $10 / 92$ & - \\
\hline Mark Curry & Sorry about the Weather & $10 / 92$ & - \\
\hline Stone Temple Pilots & Sex Type Thing & $10 / 92$ & - \\
\hline
\end{tabular}


Table I. (continued)

\begin{tabular}{|c|c|c|c|}
\hline Artist & Video & Premiere Date & Billboard Hot 100 Peak Position \\
\hline Lemonheads, The & Mrs. Robinson & $11 / 92$ & - \\
\hline $\mathrm{NIN}$ & Wish & $11 / 92$ & - \\
\hline Stereo MCs & Step it Up & $12 / 92$ & 58 \\
\hline Jesus Jones & The Devil You Know & $12 / 92$ & - \\
\hline Cranberries, The & Linger & 1/93 & 8 \\
\hline Deep Forest & Sweet Lullaby & $1 / 93$ & 78 \\
\hline Belly & Feed the Tree & $1 / 93$ & 95 \\
\hline Digable Planets & Rebirth of Slick & $2 / 93$ & 15 \\
\hline Neneh Cherry & Buddy $X$ & $2 / 93$ & 43 \\
\hline Screaming Trees & Nearly Lost You & $3 / 93$ & - \\
\hline Soul Asylum & Black Gold & $3 / 93$ & - \\
\hline Radiohead & Creep & $4 / 93$ & 34 \\
\hline Terence Trent D'Arby & She Kissed Me & $4 / 93$ & - \\
\hline Soul Asylum & Runaway Train & $5 / 93$ & 5 \\
\hline Stone Temple Pilots & Plush & $5 / 93$ & - \\
\hline Cypress Hill & Insane in the Brain & $6 / 93$ & 19 \\
\hline Porno for Pyros & Pets & $6 / 93$ & 67 \\
\hline Bjork & Human Behavior & $6 / 93$ & - \\
\hline Urge Overkill & Sister Havana & $6 / 93$ & - \\
\hline White Zombie & Thunderkiss 65 & $7 / 93$ & - \\
\hline Breeders, The & Cannonball & $8 / 93$ & 44 \\
\hline Lemonheads, The & Into Your Arms & $8 / 93$ & 67 \\
\hline US3 & Cantaloop & 9/93 & 9 \\
\hline Smashing Pumpkins & Today & $9 / 93$ & - \\
\hline Crash Test Dummies & Mmm... & $10 / 93$ & 4 \\
\hline Mazzy Star & Fade Into You & $10 / 93$ & 44 \\
\hline James & Laid & $10 / 93$ & 61 \\
\hline Tony Bennett & Steppin' Out With My Baby & $11 / 93$ & - \\
\hline Flaming Lips & She Don't Use Jelly & $12 / 93$ & 55 \\
\hline Dig & Believe & $12 / 93$ & - \\
\hline Counting Crows & Mr. Jones & $12 / 93$ & - \\
\hline RATM & Freedom & $12 / 93$ & - \\
\hline Morrissey & The More You Ignore Me, The closer I get & 2/94 & 46 \\
\hline Beck & Loser & $3 / 94$ & 10 \\
\hline Brand New Heavies & Dream On Dreamer & $3 / 94$ & 51 \\
\hline Green Day & Longview & $3 / 94$ & - \\
\hline Live & Selling the Drama & $4 / 94$ & 43 \\
\hline Frente! & Bizarre Love Triangle & $4 / 94$ & 49 \\
\hline Danzig & Mother ' 93 & $5 / 94$ & 43 \\
\hline Beastie Boys & Sabotage & $5 / 94$ & - \\
\hline Offspring & Come Out and Play & $5 / 94$ & - \\
\hline Lisa Loeb & Stay & $6 / 94$ & - \\
\hline Weezer & Undone Sweater Song & $7 / 94$ & 57 \\
\hline Veruca Salt & Seether & $7 / 94$ & - \\
\hline Green Day & Basket Case & $8 / 94$ & - \\
\hline Dinosaur Jr. & Feel the Pain & $8 / 94$ & - \\
\hline Hole & Doll Parts & $9 / 94$ & 58 \\
\hline Cranberries, The & Zombie & $9 / 94$ & - \\
\hline Rancid & Salvation & $9 / 94$ & - \\
\hline Elastica & Connection & $10 / 94$ & 53 \\
\hline Urge Overkill & Girl You'll be a Woman Soon & $10 / 94$ & 59 \\
\hline Sponge & Plowed & $11 / 94$ & - \\
\hline Letters to Cleo & Here and Now & $12 / 94$ & 56 \\
\hline Bush & Everything Zen & $12 / 94$ & - \\
\hline Live & Lightning Crashes & $12 / 94$ & - \\
\hline Offspring & Self Esteem & 2/95 & - \\
\hline Oasis & Live Forever & $2 / 95$ & - \\
\hline
\end{tabular}


Table I. (continued)

\begin{tabular}{|c|c|c|c|}
\hline Artist & Video & Premiere Date & Billboard Hot 100 Peak Position \\
\hline Toadies & Possum Kingdom & $2 / 95$ & - \\
\hline Dionne Farris & I Know & $3 / 95$ & 4 \\
\hline Better Than Ezra & Good & $3 / 95$ & 30 \\
\hline Jeff Buckley & The Last Goodbye & $3 / 95$ & - \\
\hline Shudder to Think & X-French Tee Shirt & $3 / 95$ & - \\
\hline Spearhead & Hole in the Bucket & $3 / 95$ & - \\
\hline Filter & Hey Man Nice Shot & $4 / 95$ & 76 \\
\hline Bush & Little Things & $4 / 95$ & - \\
\hline White Zombie & More Human Than Human & $4 / 95$ & - \\
\hline Sponge & Molly (I6 Candles Down the Drain) & $5 / 95$ & 55 \\
\hline Jill Sobule & I Kissed a Girl & $5 / 95$ & 67 \\
\hline Radiohead & Fake Plastic Trees & $5 / 95$ & - \\
\hline Silverchair & Tomorrow & $5 / 95$ & - \\
\hline Alanis Morissette & You Oughta Know & $6 / 95$ & 6 \\
\hline D'Angelo & Brown Sugar & $6 / 95$ & 27 \\
\hline Edwyn Collins & A Girl Like You & $6 / 95$ & 32 \\
\hline Better Than Ezra & In The Blood & $6 / 95$ & - \\
\hline Goo Goo Dolls & Name & $8 / 95$ & 5 \\
\hline PUSA & Lump & $8 / 95$ & - \\
\hline Garbage & Queer & $8 / 95$ & - \\
\hline Civ & Can't Wait One Minute More & $9 / 95$ & - \\
\hline Rancid & Time Bomb & $9 / 95$ & - \\
\hline Foo Fighters & I'll Stick Around & $9 / 95$ & - \\
\hline Oasis & Wonderwall & $10 / 95$ & 8 \\
\hline Rentals, The & Friends of $P$ & $10 / 95$ & - \\
\hline Everclear & Santa Monica & $10 / 95$ & - \\
\hline Spacehog & In the Meantime & 1/96 & 32 \\
\hline Radiohead & High and Dry & $1 / 96$ & 78 \\
\hline Goo Goo Dolls & Naked & $1 / 96$ & - \\
\hline Joan Osborne & One of Us & $2 / 96$ & 4 \\
\hline Garbage & Only Happy When it Rains & $2 / 96$ & 55 \\
\hline Dog's Eye View & Everything Falls Apart & $2 / 96$ & 66 \\
\hline Foo Fighters & $\mathrm{Big} \mathrm{Me}$ & $2 / 96$ & - \\
\hline Stabbing Westward & What Do I Have to Do? & $2 / 96$ & - \\
\hline Wallflowers, The & 6th Avenue Heartache & $2 / 96$ & - \\
\hline Prodigy & Firestarter & $3 / 96$ & 30 \\
\hline PUSA & Peaches & $4 / 96$ & 29 \\
\hline Marilyn Manson & Sweet Dreams & $4 / 96$ & - \\
\hline RATM & Bulls on Parade & $4 / 96$ & - \\
\hline Garbage & Stupid Girl & $5 / 96$ & 24 \\
\hline 311 & Down & $5 / 96$ & - \\
\hline Folk Implosion & Natural One & $6 / 96$ & 29 \\
\hline Beck & Where It's At & $6 / 96$ & 61 \\
\hline Tracy Bonham & Mother Mother & $6 / 96$ & - \\
\hline Superdrag & Who Sucked Out the Feeling & $7 / 96$ & - \\
\hline Nada Surf & Popular & $7 / 96$ & - \\
\hline Sublime & What I Got & $7 / 96$ & - \\
\hline Fiona Apple & Shadowboxer & $7 / 96$ & - \\
\hline Eels & Novocaine for the Soul & $8 / 96$ & - \\
\hline Filter & Jurrassitol & $8 / 96$ & - \\
\hline RATM & People of the Sun & $8 / 96$ & - \\
\hline Cake & The Distance & $9 / 96$ & - \\
\hline Marilyn Manson & The Beautiful People & $9 / 96$ & - \\
\hline Tool & Track \#I (“Stinkfist”) & $9 / 96$ & - \\
\hline Chemical Brothers, The & Setting Sun & $10 / 96$ & 80 \\
\hline Ginsburg/McCartney/Glass & The Ballad of the Skeletons & $10 / 96$ & - \\
\hline Prodigy & Breathe & $11 / 96$ & - \\
\hline
\end{tabular}


Table I. (continued)

\begin{tabular}{|c|c|c|c|}
\hline Artist & Video & Premiere Date & Billboard Hot 100 Peak Position \\
\hline REEF & Place your Hands & $11 / 96$ & - \\
\hline Erykah Badu & On and On & $12 / 96$ & 12 \\
\hline Roots, The & What They Do & $12 / 96$ & 34 \\
\hline Cardigans, The & Lovefool & $12 / 96$ & - \\
\hline Verve Pipe, The & The Freshman & I/97 & 5 \\
\hline Veruca Salt & Volcano Girls & $1 / 97$ & - \\
\hline Squirrel Nut Zippers & Hell & $2 / 97$ & - \\
\hline Fiona Apple & Sleep to Dream & $2 / 97$ & - \\
\hline Blur & Song 2 & $3 / 97$ & - \\
\hline Rammstein & Du Hast & $3 / 97$ & - \\
\hline Hanson & MMMBop & $4 / 97$ & I \\
\hline Daft Punk & Around the World & $4 / 97$ & 61 \\
\hline Chemical Brothers, The & Block Rockin' Beats & $4 / 97$ & - \\
\hline Fatboy Slim & Going Out of my Head & $5 / 97$ & - \\
\hline Dandy Warhols, The & Not if You Were the Last Junkie on Earth & $5 / 97$ & - \\
\hline Missy Elliott & The Rain & $5 / 97$ & - \\
\hline Radiohead & Paranoid Android & $5 / 97$ & - \\
\hline Verve, The & Bittersweet Symphony & $6 / 97$ & 12 \\
\hline Sugar Ray & Fly & $6 / 97$ & - \\
\hline Finley Quaye & Sunday Shining & $6 / 97$ & - \\
\hline Sarah McLachlan & Building a Mystery & $7 / 97$ & 13 \\
\hline Forest for the Trees & Dream & $8 / 97$ & 72 \\
\hline Cornershop & Brimful of Asha & $8 / 97$ & - \\
\hline Radiohead & Karma Police & $8 / 97$ & - \\
\hline Busta Rhymes & Put Your Hands Where My Eyes Could See & $8 / 97$ & - \\
\hline Sermon/Redman/Murray & Rapper's Delight & $10 / 97$ & - \\
\hline Space Monkeys & Sugar Cane & $11 / 97$ & - \\
\hline Bob Dylan & Not Dark Yet & $11 / 97$ & - \\
\hline Natalie Imbruglia & Torn & $12 / 97$ & 42 \\
\hline Semisonic & Closing Time & $3 / 98$ & - \\
\hline Fastball & The Way & $4 / 98$ & - \\
\hline Eve 6 & Inside Out & $6 / 98$ & 28 \\
\hline Stardust & Music Sounds Better With You & $8 / 98$ & 62 \\
\hline Robbie Williams & Millennium & $9 / 98$ & 72 \\
\hline Limp Bizkit & Faith & $11 / 98$ & - \\
\hline Fatboy Slim & Praise You & $12 / 98$ & 36 \\
\hline Lo Fidelity Allstars & Battleflag & 2/99 & - \\
\hline Ricky Martin & Livin' La Vida Loca & $3 / 99$ & I \\
\hline Eminem & My Name Is & $3 / 99$ & 36 \\
\hline Orgy & Blue Monday & $3 / 99$ & 56 \\
\hline Kid Rock & Bawitdaba & $3 / 99$ & - \\
\hline Baz Luhrman & Everybody's Free (To Wear Sunscreen) & $4 / 99$ & 45 \\
\hline Godsmack & Whatever & $4 / 99$ & - \\
\hline Jennifer Lopez & If You Had My Love & $5 / 99$ & I \\
\hline Buckcherry & Lit Up & $5 / 99$ & - \\
\hline Freestylers & Here We Go & $5 / 99$ & - \\
\hline Enrique Iglesias & Bailamos & $6 / 99$ & I \\
\hline Macy Gray & Do Something & $6 / 99$ & - \\
\hline Christina Aguilera & Genie in a Bottle & $7 / 99$ & I \\
\hline Len & Steal My Sunshine & $7 / 99$ & 9 \\
\hline Bif Naked & Moment of Weakness & $7 / 99$ & - \\
\hline Static-X & Push It & $8 / 99$ & - \\
\hline Jimmie's Chicken Shack & Do Right & $8 / 99$ & - \\
\hline Staind & Mudshovel & $8 / 99$ & - \\
\hline Eve & Gotta Man & $9 / 99$ & - \\
\hline Hot Boys & We On Fire & $9 / 99$ & - \\
\hline Macy Gray & I Try & $10 / 99$ & 5 \\
\hline Kelis & Caught out There & $10 / 99$ & 54 \\
\hline Stroke 9 & Little Black Backpack & $10 / 99$ & - \\
\hline $\begin{array}{l}\text { Powerman } 5000 \\
n=288\end{array}$ & Nobody's Real & $11 / 99$ & - \\
\hline
\end{tabular}


'Of all the things on MTV, here's what you should pay attention to"” (Entertainment Weekly, 1995).

Most Buzz Clips were from new, breakthrough artists, and most artists only got one video in the corpus. MTV tended to prioritize and promote new, emerging genres. The series focused on alternative rock, grunge, and hiphop from 1990 to 1993, and, as the decade progressed, helped introduce the world to pop-punk, music associated with the Lilith Fair Festival, electronica, and nü-metal. As such, Buzz Clips constitute a subgenre of MTV's video output in the $90 \mathrm{~s}$, and are themselves linked to particular emerging genres.

Our approach differs from methods described above in that it relies on quantitative methods to analyze this corpus of data. The most applicable antecedent for such an approach comes from music video researcher Kip Pegley's 2008 book. Pegley watched one continuous week (November 4-11, 1995) of programing on the Canadian music video network MuchMusic. Through a process known as content analysis, she recorded the frequency with which a number of pre-determined variables appeared. Her aim was to establish what kinds of people and content were being promoted through these music videos. Highlighting the concept of identity formation in the pre-internet era-especially for women and sexual/ethnic minorities-Pegley claims "Before North American teenagers began downloading on-demand videos from countries at home and abroad, MTV and MuchMusic were the two sources that shaped their lifestyle and their sense of themselves as a gendered and racially defined citizen of the United States or Canada" (Pegley, 2008, p. 15). Pegley was especially interested in how often viewers saw women playing instruments (other than the voice). ${ }^{4}$ Koskoff $(1987$, p. 7) has highlighted the importance of analyzing women's musical performance particularly because it reflects a particular society's gender structure and views regarding women's sexual identity.

Like Pegley, our analysis sets out to assess the kinds of people and cultural practices MTV promoted as buzzworthy in the 1990s. However, our analytical methods differ from those applied in Pegley's book. For example, while Pegley's statistical tools are designed to answer questions like how often black musicians were seen relative to white musicians, ${ }^{5}$ we introduce two further steps in order to answer ethnomusicologist Bruno Nettl's (2015, p. 468) challenge to bring to bear more sophisticated tools to the analysis of music and identity. First, we split the content analysis into separate quantitative and qualitative phases. Second, we apply correlational analyses to that content to more accurately describe how certain people and practices are portrayed alongside one another.

Our research activity took place across three phases. The following research questions are provided to guide the reader during the explanation of these three phases, as well as the results and discussion.
- Phase 1: What themes emerge from content analysis of the Buzz Clips corpus?

- Phase 2: To what extent are the emergent Buzz Clips themes present in the corpus?

- Phase 3: What types of relationships exist between both musical and visual qualities in Buzz Clips?

\section{Methods}

Phase One, completed in May 2017, was an exploratory, bottom-up content analysis of the marked audio-visual themes in these videos. Content analysis procedures were chosen for their suitability in analyzing frequency and trend. ${ }^{6}$ Phase Two, completed in August 2017, was a corpus study in which the primary investigator, along with two PhD candidates from musicology and film studies, reanalyzed the 288 videos from a quantitative perspective in order to determine the frequency of the 88 most common themes generated in Phase One. Phase Three, completed in December 2018, was a correlational study conducted by the secondary investigators that estimated the strength of the relationships between any two signifiers coded in Phase Two.

In Phase One, we watched all 288 videos and created codes for recurring themes in a spreadsheet. For example, the first flannel shirt appears in Alice in Chains's 1991 video "Man in the Box." After noticing this in several other videos, we created the code (Flan) to signify the emergent theme of flannel clothing. ${ }^{7}$ We inserted this code as a vertical column in a spreadsheet, creating a matrix with the 288 music videos in the horizontal rows. Any corresponding cells of music videos containing flannel shirts received a code of " 1 ". Absence of flannel resulted in a code of " 0 ". This procedure was repeated for all music videos and all emergent themes.

In order to maximize the possibility of spotting all trends, two additional research assistants acted as independent coders, watching all 288 videos separately and keeping their own independent spreadsheets. In addition to each of our individual spreadsheets, we also maintained a separate shared log of collective emergent themes and codes as they were created. As soon as new codes appeared on our shared spreadsheet, each of us began to look for instances of that theme in subsequent videos. These themes emerged as data-sensitive, authentic representations of music video analysis. The complete list of the 88 emergent themes resulting from Phase One can be found in Table 2.

The 88 emergent themes from Phase One constituted the variable set utilized in Phase Two. In Phase 2, two raters analyzed all videos for code frequencies within the thematic categories of fashion, setting, imagery, gender/sexuality/race, and narrative. Supplemental Material 1 displays the presence (marked with a " 1 ") or absence (marked with a " 0 ") of each of these 88 themes in each of the 288 videos. Per the standards of Landis and Koch (1977), we calculated Cohen's Kappa, a measure of observer agreement. Values 
Table 2. Total variables by observation frequency.

\begin{tabular}{|c|c|c|}
\hline \multicolumn{3}{|c|}{ Total variables $(n=88)$ listed by observation frequency } \\
\hline Code & Definition & Frequency \\
\hline Nice & Interview/clubbing clothing & 259 \\
\hline VC & Verse/chorus form & 259 \\
\hline Dark & Dark/black clothing & 241 \\
\hline Silly & Humorous video content & 219 \\
\hline Coll & Misc. vignettes, no storyline & 206 \\
\hline Spd & Video speed effects & 193 \\
\hline DTRK & Dolly, tracking shot & 190 \\
\hline Light & Light effects & 177 \\
\hline Zoom & Zooming shots & 168 \\
\hline Over & Overdriven guitar & 167 \\
\hline Shak & Shaky, handheld camera & 165 \\
\hline Dim & Dark lighting & 155 \\
\hline Color & Video color manipulation & 144 \\
\hline Solo & Instrumental solo & 126 \\
\hline Super & Video superimposition with fading & 123 \\
\hline Leath & Leather clothing & 121 \\
\hline Nat & Nature scenery & 121 \\
\hline Urban & Urban setting & 120 \\
\hline Mono & Black and white/monochrome video & 119 \\
\hline Alt & Significantly altered image & 113 \\
\hline LA & Vintage-looking clothing & 98 \\
\hline Water & Ocean or river setting & 96 \\
\hline $2 \mathrm{Col}$ & Multiple people of color & 95 \\
\hline Clean & No guitar distortion & 91 \\
\hline TopL & Shirtless man & 90 \\
\hline Car & Driving car, motorcycle, golf cart, etc. & 87 \\
\hline Dance & Choreographed dancing & 87 \\
\hline Dist & Heavily distorted guitar & 87 \\
\hline Perf & Band performance, no storyline & 86 \\
\hline Tank & Woman wearing tank top & 82 \\
\hline Bald & Bald man & 81 \\
\hline D.Mach & Drum machine & 77 \\
\hline Spiky & Spiky haircut on man & 73 \\
\hline Keys & Keyboard lead instrument & 70 \\
\hline Baggy & Baggy clothing & 68 \\
\hline Crop & Woman wearing cropped shirt & 68 \\
\hline Srs & Serious imagery/themes & 66 \\
\hline $8 \mathrm{~mm}$ & Grainy, compressed, blurred video & 65 \\
\hline Narr & Clear story with plot and characters & 62 \\
\hline Ac.G & Acoustic guitar use & 60 \\
\hline ExNo & Extra, non-musical noises & 60 \\
\hline Cap & Capitalist imagery & 56 \\
\hline Fade & Gradual song fadeout & 53 \\
\hline H.Bod & Large hollow body guitar pictured & 52 \\
\hline Gaze & Predatory man gaze/behavior & 49 \\
\hline Flan & Flannel shirt & 46 \\
\hline Multi & Split screen & 42 \\
\hline Pixie & Woman with pixie haircut & 42 \\
\hline SSVC & Identical/similar verse and chorus & 42 \\
\hline LP & Iconic LP guitar & 41 \\
\hline Relig & Religious/antireligious imagery & 41 \\
\hline Wfem & Lead singer is white woman & 41 \\
\hline Strat & Iconic Strat guitar & 40 \\
\hline Alc & Alcoholic drinks & 38 \\
\hline Bowl & Man with bowl haircut & 38 \\
\hline Make & Man wearing makeup & 38 \\
\hline
\end{tabular}

(continued)
Table 2. (continued)

Total variables $(n=88)$ listed by observation frequency

\begin{tabular}{|c|c|c|}
\hline Code & Definition & Frequency \\
\hline NoBand & Band performance not shown & 38 \\
\hline T.Miss & Timbral mismatch & 37 \\
\hline Orch & Brass or string instruments & 34 \\
\hline Pol & Police/military & 34 \\
\hline Digi & Digitally-created video objects & 33 \\
\hline Finst & Woman playing instrument & 33 \\
\hline Indus & Industrial setting & 33 \\
\hline Agg & Aggressive playing/instrument smashing & 32 \\
\hline Marsh & Marshall amp logo visible & 30 \\
\hline Bmal & Black man lead singer & 28 \\
\hline Str & Strophic form & 28 \\
\hline Sat & Satire/parody of product or genre & 25 \\
\hline 332 & 3-3-2 groove & 23 \\
\hline Long & Long shots & 23 \\
\hline Scr & Screaming & 23 \\
\hline Torn & Torn/tattered clothing & 23 \\
\hline Bfem & Black woman lead singer & 19 \\
\hline Nerd & Nerdy clothing & 19 \\
\hline Reflx & Video shows filming of video & 19 \\
\hline Butch & Masculine woman & 18 \\
\hline Cow & Cowboy clothing & 18 \\
\hline Tele & Iconic Tele guitar & 18 \\
\hline Mirr & Symmetrical mirror shot & 17 \\
\hline Cross & Man crossdressing & 16 \\
\hline Efem & Effeminate man behavior & 16 \\
\hline Gay & Homosexuality shown/implied & 16 \\
\hline Lace & Woman wearing lace & 16 \\
\hline SG & Iconic SG guitar & 14 \\
\hline Circ & Circus performers & II \\
\hline Dream & Dream sequence & II \\
\hline Cart & Cartoons & 10 \\
\hline 2 char & One actor plays two characters & 8 \\
\hline Movie & Film scenes used & 5 \\
\hline
\end{tabular}

were quite high in all categories, ranging from "substantial" (.61-.80) to "almost perfect" (.81-.99) in all categories: fashion (.73), setting, (.77), imagery (.69), gender/sexuality/race (.89), and narrative (.73). Music and video codes were only observed by one rater, so rater reliability was not calculated for either of these categories. Phase Two normalized the dataset by showing us exactly when trends began, regardless of when they were observed in Phase One. For example, Phase One coders only noticed pixie haircuts (Pixie) alongside the rise of women singersongwriters in 1994, but Phase Two revealed that there were several instances of pixie cuts in both 1990 and 1992.

Phases One and Two tackled the same problem from different angles. The strength of Phase One was its bottom-up assessment. It presumed nothing-viewers recorded what happened in the videos without imposing a preconceived idea of what they expected might happen. Phase Two was, instead, a top-down assessment that determined the frequencies of codes, implying the emergence, rise, and fall of these trends. Following research standards in social sciences and communication studies (Stevens, 
Table 3. Observation frequency ordered by category.

\begin{tabular}{|c|c|c|}
\hline Code & Definition & Frequency \\
\hline \multicolumn{3}{|l|}{ Fashion } \\
\hline Nice & Interview/clubbing clothing & 259 \\
\hline Dark & Dark/black clothing & 241 \\
\hline Leath & Leather clothing & 121 \\
\hline LA & Vintage-looking clothing & 98 \\
\hline TopL & Shirtless man & 90 \\
\hline Tank & Woman wearing tank top & 82 \\
\hline Bald & Bald man & 81 \\
\hline Spiky & Spiky haircut on man & 73 \\
\hline Baggy & Baggy clothing & 68 \\
\hline Crop & Woman wearing cropped shirt & 68 \\
\hline Flan & Flannel shirt & 46 \\
\hline Pixie & Woman with pixie haircut & 42 \\
\hline Bowl & Man with bowl haircut & 38 \\
\hline Make & Man wearing makeup & 38 \\
\hline Torn & Torn/tattered clothing & 23 \\
\hline Nerd & Nerdy clothing & 19 \\
\hline Butch & Masculine woman & 18 \\
\hline Cow & Cowboy clothing & 18 \\
\hline Cross & Man crossdressing & 16 \\
\hline Lace & Woman wearing lace & 16 \\
\hline \multicolumn{3}{|c|}{ Gender/Sexuality/Race } \\
\hline $2 \mathrm{Col}$ & Multiple people of color & 95 \\
\hline Gaze & Predatory male gaze/behavior & 49 \\
\hline Wfem & White female lead singer & 41 \\
\hline Finst & Woman playing instrument & 33 \\
\hline Bmal & Black male lead singer & 28 \\
\hline Bfem & Black female lead singer & 19 \\
\hline Efem & Effeminate male behavior & 16 \\
\hline Gay & Homosexuality shown/implied & 16 \\
\hline \multicolumn{3}{|l|}{ Imagery } \\
\hline Silly & Humorous video content & 219 \\
\hline Dance & Choreographed dancing & 87 \\
\hline Srs & Serious imagery/themes & 66 \\
\hline Cap & Capitalist imagery & 56 \\
\hline Relig & Religious/antireligious imagery & 41 \\
\hline Alc & Alcoholic drinks & 38 \\
\hline Pol & Police/military & 34 \\
\hline Agg & Aggressive playing/instrument smashing & 32 \\
\hline Circ & Circus performers & 11 \\
\hline \multicolumn{3}{|c|}{ Musical Elements } \\
\hline VC & Verse/chorus form & 259 \\
\hline Over & Overdriven guitar & 167 \\
\hline Solo & Instrumental solo & 126 \\
\hline Clean & No guitar distortion & 91 \\
\hline Dist & Heavily distorted guitar & 87 \\
\hline D.Mach & Drum machine & 77 \\
\hline Keys & Keyboard lead instrument & 70 \\
\hline Ac.G & Acoustic guitar use & 60 \\
\hline Fade & Gradual song fadeout & 53 \\
\hline H.Bod & Large hollow body guitar pictured & 52 \\
\hline SSVC & Identical/similar verse and chorus & 42 \\
\hline LP & Iconic LP guitar & 41 \\
\hline Strat & Iconic Strat guitar & 40 \\
\hline T.miss & Timbral mismatch & 37 \\
\hline Orch & Brass or string instruments & 34 \\
\hline Marsh & Marshall amp logo visible & 30 \\
\hline Str & Strophic form & 28 \\
\hline
\end{tabular}

(continued)
Table 3. (continued)

\begin{tabular}{|c|c|c|}
\hline Code & Definition & Frequency \\
\hline 332 & 3-3-2 groove & 23 \\
\hline Scr & Screaming & 23 \\
\hline Tele & Iconic Tele guitar & 18 \\
\hline SG & Iconic SG guitar & 14 \\
\hline \multicolumn{3}{|l|}{ Narrative } \\
\hline Coll & Misc. vignettes, no storyline & 206 \\
\hline Perf & Band performance, no storyline & 86 \\
\hline Narr & Clear story with plot and characters & 62 \\
\hline Sat & Satire/parody of product or genre & 25 \\
\hline Movie & Film scenes used & 5 \\
\hline \multicolumn{3}{|l|}{ Setting } \\
\hline Nat & Nature scenery & $|2|$ \\
\hline Urban & Urban setting & 120 \\
\hline Water & Ocean or river setting & 96 \\
\hline Car & Driving car, motorcycle, golf cart, etc. & 87 \\
\hline NoBand & Band performance not shown & 38 \\
\hline Indus & Industrial setting & 33 \\
\hline Dream & Dream sequence & II \\
\hline \multicolumn{3}{|c|}{ Video Elements } \\
\hline Spd & Video speed effects & 193 \\
\hline DTRK & Dolly, tracking shot & 190 \\
\hline Light & Light effects & 177 \\
\hline Zoom & Zooming shots & 168 \\
\hline Shak & Shaky, handheld camera & 165 \\
\hline $\operatorname{Dim}$ & Dark lighting & 155 \\
\hline Color & Video color manipulation & 144 \\
\hline Super & Video superimposition with fading & 123 \\
\hline Mono & Black and white/monochrome video & 119 \\
\hline Alt & Significantly altered image & 113 \\
\hline $8 \mathrm{~mm}$ & Grainy, compressed, blurred video & 65 \\
\hline ExNo & Extra, non-musical noises & 60 \\
\hline Multi & Split screen & 42 \\
\hline Digi & Digitally-created video objects & 33 \\
\hline Long & Long shots & 23 \\
\hline Reflx & Video shows filming of video & 19 \\
\hline Mirr & Symmetrical mirror shot & 17 \\
\hline Cart & Cartoons & 10 \\
\hline 2char & One actor plays two characters & 8 \\
\hline
\end{tabular}

2012), the blend of bottom-up and top-down methods is helpful for avoiding both selection and exposure biases.

In Phase Three we computed polychoric correlations between each of the variables to look at relationships between the various musical and non-musical aspects of each video. The commonly used Pearson correlation was not appropriate for this analysis, because it underestimates the relationship between variables in dichotomous data. We also considered analyzing purely descriptive data, but worried that this type of information lacked inferential power necessary to prompt future research on this topic. It seemed best to reference a statistical standard for guidance in our analysis, though not through the utilization of alpha to determine statistical significance. As a result, we elected to calculate tetrachoric correlation coefficients. These correlations are a special case of polychoric correlations and are appropriate for binary data (Chesire et al., 1933; Muthén \& Hofacker, 1988). The full 
Table 4. Heat map.

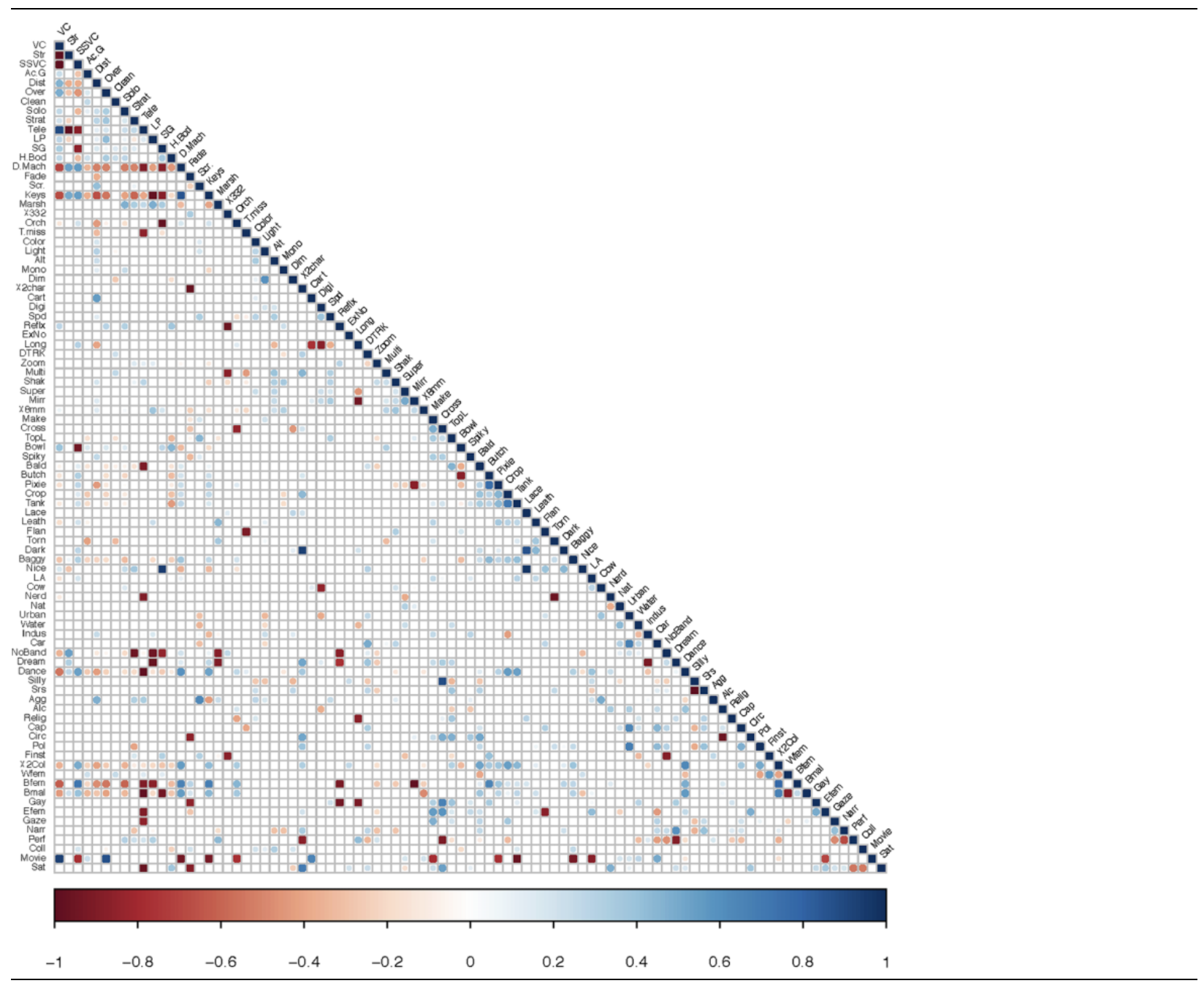

correlation matrix of all variables coded can be found in Supplemental Material 2 and Supplemental Material 3.

Using these resulting correlations, we elected to use a measure of shared variability between variables to identify relationships warranting future analysis. The variance inflation factors (VIF) references the extent of shared variability between variables through a numerical score. Truly independent variables have a VIF of zero. As the VIF increases, the degree of dependence increases. We elected to use a VIF of 5 (representing no less than $80 \%$ shared variability between fit lines) as our threshold for analysis. ${ }^{8}$ Selected relationships reflecting VIF values above 5 can be viewed in Table 5.

\section{Results and discussion}

Results of Phases 1 and 2 define the presence and magnitude of 88 emergent themes in the corpus. Table 2 shows the frequency with which the themes appear. Table 3 shows these same 88 variables ranked by observation frequency, but grouped by category.

Interpreting Table 2 is difficult because of the sheer number and variety of variables coded. It also reveals that some codes generated as a result of emergent themes in Phase One may have been too broad. For example, nice clothing (Nice) was found in 259 (89.9\%) of all videos. That a more specific signifier, leather (Leath), appears in 121 videos (42\%) gets closer to establishing a prominent fashion aesthetic for these videos. Other signifiers that drew our attention in Phase One, such as music videos that contain scenes from a motion picture (Movie), nevertheless appear as outliers in the corpus ( 5 videos, $1.7 \%$ ). In this article we focus on statistical signifiers, though it is worth considering the possibility that viewers might just as well take special notice of novel yet rare signifiers such as the appearance of movies in music video.

Table 3 separates the Table 2 data into different coding categories (e.g. Music, Fashion, Narrative), making it easier 
Table 5. Selected (moderate to strong) positive and negative correlations.

\begin{tabular}{|c|c|c|c|}
\hline Variables & r & R squared & VIF \\
\hline \multicolumn{4}{|l|}{ Musical Elements } \\
\hline \multicolumn{4}{|l|}{ Telecaster Guitar } \\
\hline Choreographed Dancing & -.983 & .966 & 29.664 \\
\hline Black Woman Lead Singer & -.899 & .808 & 5.214 \\
\hline Black Man Lead Singer & -.987 & .974 & 38.713 \\
\hline \multicolumn{4}{|l|}{ Gibson SG Guitar } \\
\hline Black Man Lead Singer & -.933 & .870 & 7.721 \\
\hline \multicolumn{4}{|l|}{ Timbral Mismatch } \\
\hline Flannel Shirt & -.907 & .823 & 5.639 \\
\hline \multicolumn{4}{|l|}{ Interview/Clubbing Clothing } \\
\hline Screaming & .941 & .885 & 8.732 \\
\hline \multicolumn{4}{|l|}{ Video Elements } \\
\hline \multicolumn{4}{|l|}{ Cartoons } \\
\hline Brass or String Instruments & -.902 & .814 & 5.365 \\
\hline Police/Military & -.902 & .814 & 5.365 \\
\hline \multicolumn{4}{|l|}{ Symmetrical Mirror Shot } \\
\hline 3-3-2 Groove & -.931 & .867 & 7.505 \\
\hline \multicolumn{4}{|l|}{ Long Shots } \\
\hline Woman in Lace & -.917 & .841 & 6.285 \\
\hline Man Crossdressing & -.917 & .841 & 6.285 \\
\hline Masculine Woman & -.944 & .891 & 9.186 \\
\hline \multicolumn{4}{|l|}{ Fashion } \\
\hline \multicolumn{4}{|l|}{ Man Crossdressing } \\
\hline Black Woman Lead Singer & -.939 & .882 & 8.455 \\
\hline Black Man Lead Singer & -.963 & .927 & 13.768 \\
\hline Band Performance, No Storyline & -.902 & .814 & 5.365 \\
\hline \multicolumn{4}{|l|}{ Man with Bowl Haircut } \\
\hline Identical/Similar Verse and Chorus & -.935 & .874 & 7.951 \\
\hline \multicolumn{4}{|c|}{ Setting } \\
\hline \multicolumn{4}{|l|}{ Dream Sequence } \\
\hline Police/Military Imagery & -.925 & .856 & 6.926 \\
\hline \multicolumn{4}{|l|}{ Imagery } \\
\hline \multicolumn{4}{|l|}{ Circus Performers } \\
\hline Interview/Clubbing Clothing & .975 & .951 & 20.253 \\
\hline Woman Instrumentalist & -.917 & .841 & 6.285 \\
\hline Black Man Lead Singer & -.946 & .895 & 9.516 \\
\hline \multicolumn{4}{|l|}{ Gender/Sexuality/Race } \\
\hline \multicolumn{4}{|l|}{ Black Woman Lead Singer } \\
\hline Cowboy Clothing & -.899 & .808 & 5.214 \\
\hline \multicolumn{4}{|l|}{ Effeminate Man } \\
\hline Cowboy Clothing & -.897 & .805 & 5.118 \\
\hline \multicolumn{4}{|l|}{ Narrative } \\
\hline \multicolumn{4}{|l|}{ Movie Footage } \\
\hline Verse/Chorus Form & .932 & .869 & 7.612 \\
\hline Keyboard Lead Instrument & -.928 & .861 & 7.204 \\
\hline Drum Machine & -.939 & .882 & 8.455 \\
\hline
\end{tabular}

to draw conclusions about the people and practices represented in this corpus. We can see that women are only shown playing instruments in roughly one of every nine videos $\left(N_{\text {Finst }}=33,11.4 \%\right)$. Black men are shown as lead vocalists $\left(N_{\text {Bmal }}=28\right)$ more often than black women $\left(N_{B f e m l}=19\right)$, with white women faring better than either $\left(N_{W f e m}=41\right)$. But those three together $(N=88)$ represent less than half of the remaining 200 videos, in which white men are depicted as lead singers. Savage et al. (2015, p. 8991) has explained the widespread disparities between men's and women's musical participation across cultures as evidence of "patriarchal restrictions on female performance."

While Pegley's discussion relates this data to a wide swath of social practices (contractual, socio-economic), her data is limited to counting the frequency of these variables. We wanted to determine not only the frequency of these variables, but also which variables were regularly seen (or not seen) together. Supplemental Material 2 shows the number of times that any pair of variables appears together in the 288 videos analyzed during the third and final phase of this project. Supplemental Material 3 displays that same information as a complete correlation matrix showing the strength and direction of the relationships between each of the 88 variables. Table 4 presents this information as a visually accessible heat map - negative correlations are red, positive correlations are blue, and the opacity of the color in each cell reflects the strength of the correlation. We are including Tables 2-4 and Supplemental Material 1, 2 and 3 as downloadable, editable .xlsx files with a CC BY-NC license in the hopes that future researchers will analyze the data to reach yet unforeseen conclusions.

Table 5 shows selected moderate-to-strong positive and negative correlations that emerged from Supplemental Material 3 and Supplemental Material 2, separated into the same categories presented in Table 3. Correlation coefficients are an index of a linear relationship between any two variables. ${ }^{9}$ Correlation coefficients imply direction: they can be either positive ( $\mathrm{X}$ and $\mathrm{Y}$ tend to appear together) or negative ( $\mathrm{X}$ and $\mathrm{Y}$ tend to appear separately). In addition, correlation coefficients communicate strength on a scale between -1 and +1 with the central point of 0 indicating no linear relationship. In other words, correlation coefficients indicated by values of \pm 1 communicate a perfect linear relationship between two variables (for every single increase/decrease of $\mathrm{X}$, a respective increase/decrease of $\mathrm{Y}$ can be expected). Values between \pm 1 imply varying relationship magnitudes, with values \pm .30 or smaller generally implying weak relationships, \pm .50 implying moderate relationships, and values of \pm .70 implying strong relationships. For the purpose of this study, though, we elected to use variance inflation factor results above our designated cutoff value (higher than 5) as standard for potential discussion. In the following paragraphs, we will address and interpret the relationships from several categories demonstrating high amounts of shared variability.

\section{Musical elements}

All three of the most common electric guitar types seen in the corpus - the Fender Stratocaster (Strat), the Gibson Les Paul (LP), and the Gibson SG (SG) - correlate negatively with women (Finst) and musicians of color ( $2 \mathrm{col})$, suggesting that the electric guitar, the most identifiable signifier of rock music, is associated with white men. By contrast, the drum machine (D.mach), an instrument that is virtually anathema to rock "authenticity" in the 90s, correlates 
strongly with musicians of color, keyboards (Keys), and choreographed dancing (Dance) regularly seen in hip-hop and $R \& B$ videos. Timbral mismatch (T.miss), in which the seen instrument does not match the heard timbre, correlates negatively with flannel shirts (Flan), the dominant fashion aesthetic of (white) grunge music.

In addition to the visual appearance of these instruments, it is hard to overstate the sonic importance of the electric guitar and drum machines in determining rock and hip-hop genres (respectively). While the latter has remained a dominant sound in the Billboard Hot 100 hits of today, the electric guitar has largely been replaced by synthesizers as a primary chording instrument. As such, it is possible that the sound of a (distorted) electric guitar playing (power) chords might signify a "throwback" 90s sound.

\section{Video elements}

In certain videos, one actor plays two separate fictional characters (2char). This correlates strongly with videos that contain dream sequences (Dream), in which the dreamt character is usually portrayed by the same actor as the dreaming character. Conversely, the presence of an actor playing two fictional characters correlates negatively with performance videos (Perf), in which the dominant narrative (or lack thereof) is the band playing on a simulated soundstage. It would be both visually confusing (and technologically demanding in the 90s) to see one musician playing alongside another played by the same actor.

\section{Fashion}

Men dressing in fashion attire or makeup generally associated with women, aka cross-dressing (Cross), appears in only sixteen videos $(5.5 \%)$, but it correlates negatively with musicians of color ( $2 \mathrm{col})$. It was more culturally acceptable in this corpus to depict white musicians transgressing masculine gender norms than it was for musicians of color. Baldness (usually intentional, i.e. shaved head; Bald) was much more common among musicians of color than white musicians.

\section{Setting}

Music videos with dream sequences (Dream) correlate negatively with videos that contain police or military imagery (Pol), suggesting that these topics were too "serious" to be depicted through dreams. They correlate positively with videos than contain well-formed narrative stories (Narr), and negatively with videos that do not (e.g., performance videos; Perf), in which the narratives are replaced by extensive footage of the band performing. Urban settings (Urban), which constitute just under half of all videos in the corpus $(41.6 \%)$, correlate strongly with themes of police, military, and capitalism (Cap), suggesting the city as the site of such cultural practices.

\section{Imagery}

Circus performers (Circ) are relatively rare in the corpus $(N=11)$, but they correlate negatively with women instrumentalists (FInst) and people of color ( $2 \mathrm{col}$ ). It could be the case that white men have the cultural capital to risk being depicted alongside such "freaks," while others do not. Extended dance sequences (Dance), a hallmark of hiphop and R\&B videos, correlate positively with other elements heard and seen in those videos, including musicians of color and use of keyboards (Keys).

\section{Gender/sexuality/race}

When black women (Bfem) appear as lead singers in these videos, they are depicted in more "butch" fashions (Butch) than white women (Wfem). They also almost never wear cowboy/western-influenced clothing (Cow). Men perceived as dressing effeminately (Efem) also disavow cowboy clothing, as well as flannel (Flan), and are regularly seen wearing makeup (Make) and/or crossdressing (Cross).

\section{Narrative}

When movie footage (Movie) does appear in Buzz Clips, it is always from a movie in which the heard song appears on the soundtrack. Though there are only 5 such videos, it is interesting that movie footage correlates strongly with a number of elements linked to rock music, including verse/chorus forms (VC) and overdriven guitars (Over). These videos correlate negatively with elements linked to hip-hop or R\&B, including drum machines (D.mach), keyboards (Keys), and musicians of color ( $2 \mathrm{col}$ ). Buzz Clips, then, promoted movies associated with white rock culture (e.g. Urge Overkill's video "Girl You'll be a Woman Soon," promoting Pulp Fiction) but not hip-hop videos promoting black culture (e.g. Dr. Dre's video for "Keep Their Heads Ringin'," promoting the movie Friday).

\section{Conclusion}

This article has introduced quantitative methods for the analysis of a corpus of music videos, has discussed some of the most common elements observed in those videos, and has attempted to interpret some of the correlations between those elements. We are making the data available to music video researchers in the hopes that it will promote future research along these lines by other scholars.

\section{Action editor}

Tecumseh Fitch, University of Vienna, Department of Cognitive Biology.

\section{Declaration of conflicting interests}

The author(s) declared no potential conflicts of interest with respect to the research, authorship, and/or publication of this article. 


\section{Funding}

The author(s) received no financial support for the research, authorship, and/or publication of this article.

\section{ORCID iD}

Brad Osborn (D) https://orcid.org/0000-0001-7573-9318

Kevin Weingarten (D) https://orcid.org/0000-0002-5346-4760

\section{Contributorship}

BO researched literature and conceived the study. ER and KW were involved in empirical design and data analysis. All authors drafted, reviewed, and edited the manuscript and approved the final version of the manuscript.

\section{Peer review}

Patrick Savage, Keio University Shonan Fujisawa Campus, Faculty of Environment and Information Studies.

Carol Vernallis, Stanford University, Department of Music.

\section{Supplemental material}

Supplemental material for this article is available online.

\section{Notes}

1. See Burns 2017, as well as several of the chapters in Hawkins (2017).

2. Buzz clips actually began, modestly, in 1987 , and petered out in 2004. There were only 14 buzz clips in 1987, and 4 in 2004. In each year of the 1990s there were, on average, $29.3 \mathrm{buzz}$ clips per year.

3. We were able to archive this website, which lists the total Buzz Clips for each year, before it was removed. We then crossreferenced it with Billboard's Video Monitor list for select years to check for accuracy.

4. Lafrance et al. (2018) have applied a similar statistical analysis to the success of music made by women as measured in Billboard chart data.

5. Pegley reveals that First Nations, Hispanic, Asian, and other ethnic identities are rare enough so as to be rendered statistically insignificant in Pegley's week-long sample (Pegley, 2008, p. 118).

6. See Krippendorff (2013) for rationale and procedures guiding content analysis research.

7. Codes will appear in parentheses as their corresponding coded themes are discussed in the document.

8. See Thompson et al. (2017) for more information on the VIF and its supported cutoff values.

9. See Thorndike and Thorndike-Christ (2010) for further explanation of correlational analysis.

\section{References}

Balaji, M. (2010). Vixen resistin': Redefining black womanhood in hip-hop music videos. Journal of Black Studies, 41, 5-20.

Banks, J. (1997). Video in the machine: The incorporation of music video into the recording industry. Popular Music, 16, 293-309.
Benson-Allott, C. (2013). Going Gaga for glitch: Digital failure @ nd feminist spectacle in twenty-first century music video. In C. Vernallis, A. Herzog, \& J. Richardson (Eds.), The Oxford handbook of sound and image in digital media (pp. 127-137). Oxford: Oxford University Press.

Burns, L. (2017). Multimodal Analysis of Popular Music Video: Genre, Discourse, and Narrative in Steven Wilson's "Drive Home". In C. X. Rodriguez (Ed.), Coming of age: Teaching and learning popular music in academia. Ann Arbor, MI: Michigan Publishing, University of Michigan Library. doi: 10.3998/mpub.9470277

Caston, E. (2017). "The first cut is the deepest": Excerpts from a focus group on editing music videos, with explanatory historical and theoretical notes. Music, Sound, and the Moving Image, 11, 99-118.

Chesire, L., Saffir, M., \& Thurstone, L. L. (1933). Computing diagrams for the tetrachoric correlation coefficient. Chicago, IL: University of Chicago Press.

Hawkins, S. (Ed). (2017). The Routledge companion to popular music and gender. London: Routledge.

Korsgaard, M. B. (2013). Music video transformed. In C. Gorbman, J. Richardson, \& C. Vernallis (Eds.), The Oxford handbook of new audiovisual aesthetics (pp. 501-521). Oxford: Oxford University Press.

Koskoff, E. (Ed.). (1987). Women and music in cross-cultural perspective. New York: Greenwood Press.

Krippendorff, K. (2013). Content analysis: An introduction to its methodology (3rd ed.). Thousand Oaks, CA: Sage.

Lafrance, M., \& Burns, L. (2017). Finding love in hopeless places: Complex relationality and impossible heterosexuality in popular music videos by Pink and Rihanna. Music Theory Online, $23,1-17$.

Lafrance, M., Worcester, L., \& Burns, L. (2018). Gender and the billboard top 40 charts between 1997 and 2007. Popular Music and Society, 41, 557-570.

Landis, J. R., \& Koch, G. G. (1977). The measurement of observer agreement for categorical data. Biometrics, 33, 159-174.

Muthén, B., \& Hofacker, C. (1988). Testing the assumptions underlying tetrachoric correlations. Psychometrika, 53, 563-577. https://doi.org/10.1007/BF02294408

Nettl, B. (2015). The study of ethnomusicology: Thirty-three discussions (3rd ed.). Urbana, IL: University of Illinois Press.

Pegley, K. (2008). Coming to you wherever you are: Muchmusic, $M T V$, and youth identities. Middletown, CT: Wesleyan University Press.

Reid-Brinkley, S. R. (2008). The essence of res(Ex)pectability: Black women's negotiation of black femininity in rap music and music video. Meridians, 8, 236-260.

Savage, P. E., Brown, S., Sakai, E., \& Currie, T. E. (2015). Statistical universals reveal the structures and functions of human music. Proceedings of the National Academy of Sciences, 112, 8987-8992.

Staff, Entertainment Weekly. (1995, March 17). Taking care of Buzz-Iness: Meet alternative rock's best friend. Entertainment Weekly. http://www.ew.com/ew/article/0,,296425,00. html 
Stevens, J. P. (2012). Applied multivariate statistics for the social sciences (5th ed.). London: Routledge.

Thompson, C. G., Kim, R. S., Aloe, A. M., \& Becker, B. J. (2017). Extracting the variance inflation factor and other multicollinearity diagnostics from typical regression results. Basic and Applied Social Psychology, 39, 81-90.
Thorndike, R. M., \& Thorndike-Christ, T. (2010). Measurement and evaluation in psychology and education (8th ed.). London: Pearson.

Vernallis, C. (2013). Music video's second aesthetic? In C. Gorbman, J. Richardson, \& C. Vernallis (Eds.), The Oxford handbook of new audiovisual aesthetics (pp. 437-465). Oxford: Oxford University Press. 